\title{
Lifetime Performance of HF x GIR Half breed Cows in Intensive Management Conditions
}

\author{
S.S. Jadhav ${ }^{1}$, D.K. Deokar ${ }^{2}$, Y.G. Fulpagare ${ }^{3}$, U.Y. Bhoite ${ }^{4}$, \\ S.D. Mandkmale ${ }^{5}$ and C.V. Nimbalker ${ }^{6}$ \\ ${ }^{1}$ RCSM College of Agriculture, Kolhapur, Maharashtra - 416 003, India \\ ${ }^{2}$ College of Agriculture, Dhule, India \\ ${ }^{3}$ Department of Animal Husbandry and Dairy Science, Mahatma Phule Krishi Vidyapeeth, \\ Rahuri, India \\ ${ }^{4}$ Research Cum Development Project on Cattle, Mahatma Phule Krishi Vidyapeeth, Rahuri, \\ India \\ ${ }^{5}$ AICRP on Goat, Mahatma Phule Krishi Vidyapeeth, Rahuri, India \\ ${ }^{6}$ Department of Statistics, Mahatma Phule Krishi Vidyapeeth, Rahuri, India \\ *Corresponding author
}

\section{A B S T R A C T}

The research data spread over a period of 41 years (1974 to 2015) were utilized to study the heritability, genetic and phenotypic correlation of life time performance traits. The mixed model analysing using LSML were used for estimation of variance components

Keywords considering sire as a random effect, season and period of birth and age at first calving groups as fixed effects. Period of birth was highly significant on LTMY3, LTMY4,

Heritability estimates, Life time performance traits, HF x Gir cattle

\section{Article Info}

Accepted:

18 May 2019

Available Online:

10 June 2019
ALTMY, HL and PL whereas non-significant on BE. Season of birth did not influence any of the trait considered in the study. Age at first calving group had non-significant effect expect PL. The sire had significant effect on HL and PL and non-significant effect on LTMY3, LTMY4, ALTMY and BE. The overall least squares means of life time traits were $8770.95149 \mathrm{~kg}$ (LTMY3), $12127.85233 \mathrm{~kg}$ (LTMY4), $14920.46525 .16 \mathrm{~kg}$ (ALTMY), 2771.7852 .26 (HL), 1688.5952 .05 (PL) days and 82.620 .83 (BE \%), respectively. Heritability estimates of LTMY3, LTMY4 and ALTMY were (0.23 0.13; 0.290 .10 and 0.170 .43$)$. Whereas the heritability estimates for HL, PL and BE $(0.230 .14$, 0.140 .13 and 0.060 .11 ). The heritability estimates of lifetime traits had low to medium magnitude indicating that these traits can be improved through selection. While low heritability of BE indicating that this trait was influenced to a greater extent by non-genetic causes and can be improved through better management. The genetic and phenotypic correlations of LTMY3 and LTMY4 with other lifetime traits were high and positive.

\section{Introduction}

Animal husbandry and dairying has been an integral part of Indian culture since time immemorial. The majority of the vegetarian population of the country depends mainly on the milk and milk products to meet their requirement of animal protein of high biological value and trace nutrients. It forms an important livelihood activity for most of 
the farmers, supporting agriculture in the form of critical inputs, contribute into the health and nutrition of the household, supplementing income, offering employment opportunities, and finally being a dependable "bank on hooves" in times of need. Milk production and reproductive performance are the two major factors with respect to overall efficiency and profitability of the dairy animals. Nonetheless, for many years dairy cattle breeding programmes are mainly oriented towards improving the production traits and have not given due weightage to the reproduction traits. However, the rise in milk production has been shadowed by a decline in reproduction over the years.

The overall productivity of a dairy animal depends on its lifetime performance rather than on a single lactation performance. A number of factors, viz., total period of stay of a cow in a herd, number of calves dropped during entire lifetime determine the economic productivity of a cow. Once the genetic constitution of a cow is established, genetic and other non-genetic factors come into play over her lifetime performance.

Moreover, the animal breeder is also interested in improvement of lifetime production and reproduction of dairy cows for overall profitability. Further, decline in reproduction performance is likely to have a negative effect on herd life or stayability of the animals, as productivity of the animals in terms of lifetime milk production will be lowered (Togashi and Lin, 2004). Therefore, the present study was conducted to study the influence of genetic and non-genetic factors on various lifetime performance traits of $\mathrm{HF} x$ Gir half bred.

\section{Materials and Methods}

The performance records of 421 daughter of 48 sires maintained at Research Cum
Development Project on Cattle of Mahatma Phule Krishi Vidyapeeth, Rahuri, Dist. Ahmednagar of Maharashtra(India) during 1974 to 2015 were analyzed. Cows with abnormal and incomplete records were excluded from the study. Animals were managed under uniform managemental conditions and standard feeding practices. All the animals were reared in loose housing and adequate prevention measures were taken against diseases. The traits considered for evaluation of lifetime performance of $\mathrm{HF} x$ Gir halfbred cows were LTMY3(Life time milk yield upto $3^{\text {rd }}$ lactation), LTMY4(Life time milk yield upto $4^{\text {th }}$ lactation), actual life time milk yield(ALTMY): Sum of milk yield for all the lactation. Productive life(PL): Date of first calving to date of last lactation dry period, herd life(HL): Date of birth to date of disposal and breeding efficiency(BE) by $\mathrm{BE}(\%)=[365(\mathrm{~N}-1) \quad 100 / \mathrm{D}] \mathrm{Wicox}(1957)$ formula.

To examine the influence of various nongenetic factors the data was classified into 7 period of birth viz., $\mathrm{P}_{1}$ (1974-80), $\mathrm{P}_{2}$ (1981-87), $\mathrm{P}_{3}$ (1988-94), $\mathrm{P}_{4}(1995-2000), \quad \mathrm{P}_{5}$ (2001-2008) and $\mathrm{P}_{6}(2009-2015)$. Season of birth viz., rainy, winter and summer and 3 different age at first calving groups. The mixed model analysis using least squares minimum likelihood(LSML) programme Harvey(1990) was used for determining the influence of genetic and non-genetic factors on life time performance traits and estimation of genetic parameters simultaneously in which period of birth, season of birth and age at first calving group as fixed effects and sires as random effect.

\section{Results and Discussion}

The overall least squares mean for LTMY3, LTMY4 and ALTMY were estimated as $8770.95 \pm 149 \mathrm{~kg}, 12127.85 \pm 233$ and $14920.46 \pm 525.16 \mathrm{~kg}$, respectively. 
Dash(2014) reported higher estimates for LTMY3 and LTMY4(12715 $\pm 227 \mathrm{~kg}$ and $17720 \pm 339 \mathrm{~kg}$ ) in Karan Fries cattle at NDRI farm than the present study. Rathee (2015) reported similar estimates for LTMY3 and LTMY4 (9100.81 \pm 187.85 and 1869.91 \pm 375.09) in Frieswal cattle. Katore (2004) reported similar ALTMY as 13880.41 \pm $1180.20 \mathrm{~kg}$ in Gir halfbreds. Whereas Raheja (1994) and Joshi (2009) reported higher ALTMY as $20833 \pm 227 \mathrm{~kg}$ in HF Sahiwal crosses and $25819.07 \pm 887.4 \mathrm{~kg}$ in FG crossbred, respectively.

The ANOVA revealed that the effect due to season of birth on all the lifetime performance trait except $\mathrm{BE}$ were non-significant the findings were in agreement with Ambhore et al., (2017) in Phule Triveni cattle. However, Raheja (1994) and Khan and Kachwaha (2008) reported significant effect of season of birth in HF x S crossbred and in Rathi cattle, respectively. The period of birth had significant effect on all life time traits. Similar findings were observed by Dash (2014) in Karan Fries cows Ambhore et al., (2017) in Phule Triveni cattle. However, Kharat et al., (2008) reported non-significant effect in HF crossbred cattle.

The DMRT showed that lifetime total milk yield in cows born during period $\mathrm{P}_{3}(14744.46$ $\pm 1210 \mathrm{~kg}), \mathrm{P}_{4}(14204.72 \pm 1215 \mathrm{~kg})$ and $\mathrm{P}_{6}(11850.68 \pm 15.57 \mathrm{~kg})$ was significantly higher than cows born in $\mathrm{P}_{1}$ and $\mathrm{P}_{2}$ and at par with $\mathrm{P}_{5}$ period. Whereas highest LTMY3 and LTMY4 was observed in period $\mathrm{P}_{1}$ and lowest in period $\mathrm{P}_{3}$ indicating that differential management practices over the period as well as the set of sires used.

The overall least squares means for HL, PL and BE were $2771.78 \pm 52.26$ days, $1688.59 \pm$ 52.05 days and $82.62 \pm 0.83 \%$, respectively (Table 1). Dash (2014) and Rathee (2015) reported herd life $2571.25 \pm 27.31$ and
$2928.29 \pm 145.43$ days in Karan fries and Frieswal cattle, respectively. Rathee(2015) reported higher productive life than the present study(2008.81 \pm 107.82 days $)$.

The higher estimates of BE than the present study were reported by Zol et al., (2009) and Kolhe(2011) in Phule Triveni and 5/8 Gir crossbred as $92.71 \pm 0.66 \%$ and $83.47 \pm 0.81$ $\%$, respectively. Period of birth had significant effect on all trait. However, season of birth had significant on BE and nonsignificant on PL and HL. Effect of age at first calving group had significant effect on PL and non-significant on HL and BE and effect of sire had significant on HL and PL and non- significant on BE.

(Figures along the diagonal are the heritability estimates. The value above and below the diagonal are genetic and phenotypic correlations).

The heritability estimates for milk yield traits viz., LTMY3, LTMY4 and ALTMY were found to be $0.23 \pm 0.13,0.29 \pm 0.10$ and 0.11 \pm 0.12 , respectively indicating low to medium. Whereas, the heritability estimates for HL, PL and BE were 0.23 $\pm 0.14,0.14 \pm$ 0.13 and $0.06 \pm 0.11$, respectively indicating that these traits were influenced to a greater extent by non-genetic causes and can be improved through better management.

The genetic correlations of lifetime milk yield upto 3 lactation (LTMY3) with actual lifetime milk yield (ALTMY), herd life (HL) and productive life (PL) ranged between $0.13 \pm$ 0.46 to 0.36 and phenotypic correct were 0.09 \pm 0.32 to $0.39 \pm 0.04$. Genetic and phenotypic correlation LTMY4 with other traits viz., ALTMY, HL, PL and BE ranged between $0.15 \pm 0.10$ to $0.89 \pm 0.50$ and $0.14 \pm 0.64$ to $0.48 \pm 0.61$, respectively. The high positive and strong genetic correlations with in these traits indicated that these traits are near 
identical traits and performing selection on one measure will increase the genetic values of other measures.

Dubey and Singh (2005), Ambhore et al., (2017) also reported highly positive genetic correlations among different lifetime traits in Karan Swiss and Phule Triveni cattle, respectively. Breeding efficiency had negative genetic and phenotypic correlation with LTMY3, LTMY4, ALTMY and HL whereas positive with PL.

Herdlife and productive life had high positive genetic $(0.78 \pm 0.02)$ and phenotypic $(0.59 \pm$
0.34) correlation. Phenotypic correlation between actual lifetime milk yield (ALTMY) and Herd life (HL), Productive life (PL) were $(0.67 \pm 0.60)$ and $(0.19 \pm 0.75)$ respectively.

However genetic correlation between ALTMY with HL and PL were high and significant $(0.89 \pm 0.50)$ and $(0.59 \pm 0.34)$. The genetic and phenotypic correlations between important lifetime performance traits were quite high this would help in culling the unproductive and remunerative animals at any stage of life (Table 3-4).

Table.1 Least squares analysis of variance of lifetime traits(LTMY3 and LTMY4)

\begin{tabular}{|c|c|c|}
\hline \multirow{2}{*}{ Source of variation } & \multicolumn{2}{|c|}{ Mean } \\
\cline { 2 - 3 } & LTMY3 & LTMY4 \\
\cline { 2 - 3 } & MSS & MSS \\
\hline Period of birth & $109835566.09 * *$ & $156254013.11^{* *}$ \\
\hline Season of birth & 1600145.91 & 2502075.24 \\
\hline Age at first calving group & 4805304.04 & 73715.84 \\
\hline Sire & 5876144.67 & 9248550.58 \\
\hline Error & $\mathbf{6 7 5 7 3 4 4 . 7 3}$ & $\mathbf{1 1 8 3 1 2 6 8 . 3 1}$ \\
\hline ** $\mathrm{P}<0.01 \quad$ & \\
\hline
\end{tabular}

Table.2 Least squares analysis of variance of lifetime production and reproduction traits

\begin{tabular}{|c|c|c|c|c|}
\hline $\begin{array}{c}\text { Source of } \\
\text { variation }\end{array}$ & \multicolumn{4}{|c|}{ Mean sum of squares } \\
\cline { 2 - 5 } Period of birth & $299196320.6^{* *}$ & $1817796.89^{* *}$ & $2394986.37 * *$ & $\mathbf{6 4 2 . 1 0} * *$ \\
\hline Season of birth & 7394621.90 & 16172.67 & 17458.24 & $\mathbf{6 5 8 . 7 7 *}$ \\
\hline $\begin{array}{c}\text { Age at first } \\
\text { calving group }\end{array}$ & 95676973.09 & $1776241.07^{*}$ & 353591.50 & $\mathbf{7 3 . 0 1}$ \\
\hline Sire & 75985700.54 & $1243623.41^{* *}$ & $1429699.48^{* *}$ & $\mathbf{1 7 9 . 6 9}$ \\
\hline Error & $\mathbf{5 9 2 9 6 0 0 3 . 7 7}$ & $\mathbf{5 2 0 0 8 0 . 6 6}$ & $\mathbf{5 2 2 1 6 1 . 4 6}$ & $\mathbf{2 0 8 . 2 2}$ \\
\hline * $<<0.05$ and $* * \mathrm{P}<0.01$ & & & \\
\hline
\end{tabular}


Table.3 Least squares means of lifetime milk production and reproduction traits as affected by various factors

\begin{tabular}{|c|c|c|c|c|c|c|c|c|c|}
\hline \multirow[t]{2}{*}{ Source of variation } & \multirow[t]{2}{*}{$\mathbf{N}$} & $\begin{array}{l}\text { LTMY3 } \\
(\mathrm{kg})\end{array}$ & \multirow[t]{2}{*}{$\mathbf{N}$} & $\begin{array}{l}\text { LTMY4 } \\
(\mathbf{k g})\end{array}$ & \multirow[t]{2}{*}{$\mathbf{N}$} & ALTMY(kg) & \multirow{2}{*}{\begin{tabular}{|c|} 
Herd \\
life(HL)(days \\
Mean \pm S.E.
\end{tabular}} & \multirow{2}{*}{$\begin{array}{c}\text { Productive } \\
\text { life(PL)(days } \\
\text { Mean } \pm \text { S.E. }\end{array}$} & \multirow{2}{*}{$\begin{array}{c}\text { BE(\%) } \\
\text { Mean } \pm \text { S.E }\end{array}$} \\
\hline & & Mean \pm S.E. & & Mean \pm S.E. & & Mean \pm S.E. & & & \\
\hline Overall mean $(\mu)$ & 314 & $8770.95 \pm 149$ & 233 & $12127.85 \pm 233$ & 421 & $14920.46 \pm 525.16$ & $\begin{array}{c}2771 . \overline{7} 8 \pm \\
52.26\end{array}$ & $\begin{array}{c}1688.59 \pm \\
52.05\end{array}$ & $82.62 \pm 0.83$ \\
\hline \multicolumn{10}{|l|}{ Periods of birth } \\
\hline$P_{1}(1974-1980)$ & 114 & $11499.96 \pm 290^{\mathrm{a}}$ & 93 & $15424.14 \pm 426^{\mathrm{a}}$ & 157 & $19356.63 \pm 1016^{\mathrm{a}}$ & $\begin{array}{c}2563.91 \pm \\
102^{c}\end{array}$ & $1551.93 \pm 102$ & $86.89 \pm 1.63$ \\
\hline$P_{2}(1981-1987)$ & 37 & $9181.60 \pm 371^{b}$ & 21 & $13499.98 \pm 658^{b}$ & 61 & $12828.93 \pm 1301^{b c}$ & $\begin{array}{c}2212.65 \pm \\
117^{d}\end{array}$ & $\begin{array}{c}1214.11 \pm \\
116^{\mathrm{b}}\end{array}$ & $87.00 \pm 1.86$ \\
\hline$P_{3}(1988-1994)$ & 44 & $7757.69 \pm 345.7^{\mathrm{c}}$ & 33 & $10431.58 \pm 528^{c}$ & 54 & $14744.46 \pm 1210^{\mathrm{bc}}$ & $\begin{array}{c}3011.48 \pm \\
125^{\mathrm{ab}}\end{array}$ & $\begin{array}{c}1910.75 \pm \\
125^{\mathrm{ab}}\end{array}$ & $80.49 \pm 2.00$ \\
\hline$P_{4}(1995-2000)$ & 46 & $7927.2 \pm 347.0^{c}$ & 35 & $11318.66 \pm 516^{c}$ & 70 & $14204.72 \pm 1215^{b c}$ & $\begin{array}{c}2732.85 \pm \\
113^{\mathrm{bc}}\end{array}$ & $\begin{array}{c}1596.08 \pm \\
113^{\mathrm{bc}}\end{array}$ & $\begin{array}{l}82.40 \pm \\
1.81^{\text {abc }}\end{array}$ \\
\hline$P_{5}(2002-2008)$ & 37 & $8458.2 \pm 379.0^{b c}$ & 30 & $11871.88 \pm 555^{b c}$ & 50 & $16537.32 \pm 1327^{\mathrm{ab}}$ & $\begin{array}{c}3203.28 \pm \\
1.33^{\mathrm{a}}\end{array}$ & $\begin{array}{c}2022.98 \pm \\
132^{\mathrm{a}}\end{array}$ & $\begin{array}{c}80.90 \pm \\
2.12^{\text {bc }}\end{array}$ \\
\hline$P_{6}(2009-2015)$ & 26 & $7800.9 \pm 444.6^{c}$ & 21 & $10220.8 \pm 653.2^{c}$ & 29 & $11850.68 \pm 1557^{c}$ & $\begin{array}{c}2906.50 \pm \\
1.69^{\mathrm{abc}}\end{array}$ & $\begin{array}{c}1835.69 \pm \\
169^{\mathrm{abc}}\end{array}$ & $78.05 \pm 2.70$ \\
\hline \multicolumn{10}{|l|}{ Season of birth } \\
\hline$S_{1}$ : Rainy & 110 & $8906.27 \pm 242.7$ & 82 & $12282.95 \pm 354$ & 137 & $15778.86 \pm 849$ & $2813.48 \pm 84.1$ & $1731.05 \pm 84$ & $85.12 \pm 1.34$ \\
\hline $\mathbf{S}_{2}:$ Winter & 119 & $8769.43 \pm 226.3$ & 96 & $12201.83 \pm 336$ & 157 & $15040.47 \pm 792$ & $\begin{array}{c}2827.66 \pm \\
78.82\end{array}$ & $1757.91 \pm 78$ & $81.01 \pm 1.25$ \\
\hline $\mathbf{S}_{3}:$ Summer & 85 & $8637.20 \pm 250.7$ & 55 & $11898.78 \pm 412$ & 127 & $13941.53 \pm 878$ & $\begin{array}{c}2674.20 \pm \\
83.63\end{array}$ & $1576.82 \pm 83$ & $\begin{array}{c}81.73 \pm \\
1.33^{\mathrm{ab}}\end{array}$ \\
\hline \multicolumn{10}{|l|}{ Age group } \\
\hline$A_{1}:<905$ days & 171 & $8587.13 \pm 237.62$ & 136 & $12124.13 \pm 353.9$ & 232 & $15935.32 \pm 832$ & $2806.20 \pm 85$ & $1831.91 \pm 84$ & $81.61 \pm 1.35$ \\
\hline$A_{2}: 950-1050$ days & 53 & $8637.75 \pm 313.28$ & 41 & $12088.9 \pm 469.2$ & 75 & $15275.23 \pm 1097$ & $2826.63 \pm 10^{\prime}$ & $\begin{array}{c}1753.87 \pm \\
106^{\mathrm{a}}\end{array}$ & $82.87 \pm 170$ \\
\hline $\begin{array}{l}A_{3}: 1051 \text { days and } \\
\text { Above }\end{array}$ & 80 & $9087.96 \pm 270.08$ & 56 & $12170.4 \pm 426.9$ & 114 & $13550.81 \pm 945$ & $\begin{array}{c}2682.51 \pm \\
93.30\end{array}$ & $1479.99 \pm 93^{l}$ & $83.39 \pm 1.48$ \\
\hline
\end{tabular}

Means under each class in the same column with different super scripts differ significantly 
Table.4 Estimates of heritability, genetic and phenotypic correlations among different lifetime performance traits

\begin{tabular}{|l|c|c|c|c|c|c|}
\hline Trait & LTMY3 & LTMY4 & ALTMY & HL & PL & BE \\
\hline LTMY3 & $0.23 \pm$ & $0.48 \pm$ & $0.23 \pm$ & $0.13 \pm$ & $0.74 \pm$ & $-0.14 \pm$ \\
& 0.13 & $0.61^{* *}$ & $0.08^{* *}$ & 0.05 & $0.36^{* *}$ & $0.10^{*}$ \\
\hline LTMY4 & $0.38 \pm$ & $0.29 \pm$ & $0.52 \pm$ & $0.89 \pm$ & $0.59 \pm$ & $-0.15 \pm$ \\
& 0.44 & 0.10 & $0.14^{* *}$ & $0.50^{* *}$ & $0.34^{* *}$ & $0.10^{*}$ \\
\hline ALTMY & $0.30 \pm$ & $0.37 \pm$ & $0.11 \pm$ & $0.41 \pm$ & $0.40 \pm$ & $-0.24 \pm$ \\
& 0.15 & $0.28^{* *}$ & 0.12 & 0.04 & 0.04 & 0.05 \\
\hline HL & $0.10 \pm$ & $0.31 \pm$ & $0.67 \pm$ & $0.23 \pm$ & $0.78 \pm$ & $-0.39 \pm$ \\
& 0.46 & 0.47 & 0.60 & 0.14 & 0.02 & 0.04 \\
\hline PL & $0.09 \pm$ & $0.14 \pm$ & $0.19 \pm$ & $0.59 \pm$ & $0.14 \pm$ & $-0.22 \pm$ \\
& 0.32 & 0.64 & 0.75 & 0.34 & 0.13 & 0.04 \\
\hline BE & $\mathbf{0 . 3 9} \pm$ & $\mathbf{- 0 . 4 7} \pm$ & $\mathbf{- 0 . 1 9} \pm$ & $\mathbf{- 0 . 4 9} \pm$ & $\mathbf{0 . 0 3} \pm$ & $\mathbf{0 . 0 6} \pm$ \\
& $\mathbf{0 . 0 4}$ & $\mathbf{0 . 0 4} * *$ & $\mathbf{0 . 8 9}$ & $\mathbf{0 . 6 8}$ & $\mathbf{0 . 8 8}$ & $\mathbf{0 . 1 1}$ \\
\hline
\end{tabular}

\section{Impact}

The season of birth had non-significant effects on almost all life time performance traits of study. The period of birth were significant indicating fluctuations in management over the periods under study. Effect of age at first calving group on PL were significant in $\mathrm{HF} \times$ Gir cattle. The heritability estimate of LTMY-3, LTMY-4 and ALTMY were $0.23 \pm 0.13,0.29 \pm 0.10$ and $0.11 \pm 0.12$, respectively which were higher than PL and BE. However, the genetic and phenotypic correlations of LTMY4 with herd life and productive life were higher than those of other traits. The higher heritability and correlations indicated that(LTMY4) lactation milk yield upto four lactation was better representative trait among all life time performance traits under study. These results suggested that selection of relatives on the basis of lactation milk yield upto four lactation may be more appropriate.

\section{Acknowledgment}

The authors wish to express their gratitude to the Vice- Chancellor, MPKV, Rahuri for providing necessary facilities for conducting the investigation.

\section{References}

Ambhore, G.S., Singh, A., Deokar, D.K., Singh, M. and Sahoo, S.K. 2107. Life time performance of Phule Triveni synthetic cows at an organized farm. Indian J. Anim. Sci. 87(11): 14061409.

Dash, S.K., 2014 Genetic evaluation of Karan Fries cattle for fertility and production traits. Ph. D. Thesis, National Dairy Research Institute, Karnal, India.

Dubey, P.P. and Singh, C.V. 2005. Estimates of genetic and phenotypic parameters considering first lactation and lifetime performance traits in Sahiwal and crossbreed cattle. Indian J. Anim. Sci., 75(2): 1289-1294.

Harvey, W.R. 1990. Guide for LSMLMW, PC-1 Version, mixed model least squares and maximum likelihood computer programme, January 1990. Mimeograph Ohio State Univ., USA.

Katore, S.B. 2004. Studies on lifetime milk production performance of Holstein 
Friesian x Gir halfbreds. Unpublished thesis of M.Sc.(Agri.) submitted to MPKV, Rahuri.

Khan, H.M. and Kachwaha, R.N. 2008. Lifetime performance of Rathi cattle at an organized farm. Indian J. Anim. Res. 42(3): 186-190.

Kramer, C.V. 1957. Extension of multiple range test to group correlated adjusted mean. Biometric., 13: 13-20.

Raheja, K.L. 1994. Genetic parameters for first lactation and lifetime production traits in Friesian $x$ Hariana and Friesian x Sahiwal halfbreds estimated by multiple traits maximum likelihood procedure. Indian J. Anim. Sci. 64(6): 616-621.

Rathi, S. 2015. Genetic evaluation of Frieswal cattle for life time traits. Ph.D. Thesis submitted to ICAR National Dairy
Research Institute, Deemed University, Karnal(Haryana), India.

Togashi, K., and Lin, R.L. 2004. Efficiency of different selection criteria for persistency and lactation milk yield. $J$. Dairy. Sci. 87:1528-1535.

Willcox, C.J., Pfau, K.O. and Bartlett, J.W. 1957. An investigation of the inheritance of female reproductive performance and longevity and their inter-relationship within a Holstein Friesian herd. J. Dairy Sci. 40: 92447.

Zol, S.R., Bhoite, U.Y., Pachpute, S.T. and Deokar, D.K. 2009. Reproduction and production performance and breeding efficiency of Phule Triveni crossbred cows. J. Maha. Agric. Univ., 2009, Vol. 34 No. 2pp. 208-210.

\section{How to cite this article:}

Jadhav, S.S., D.K. Deokar, Y.G. Fulpagare, U.Y.Bhoite, S.D. Mandkmale and Nimbalker, C.V. 2019. Lifetime Performance of HF x GIR Half breed Cows in Intensive Management Conditions. Int.J.Curr.Microbiol.App.Sci. 8(06): 3275-3281.

doi: https://doi.org/10.20546/ijcmas.2019.806.390 